Annals of Pure and Applied Mathematics

Vol. 13, No. 2, 2017, 185-197

ISSN: 2279-087X (P), 2279-0888(online)

Published on 6 April 2017

www.researchmathsci.org

DOI: http://dx.doi.org/10.22457/apam.v13n2a4

\section{Annals of}

Pure and Applied

Mathematics

\title{
An Econometric Analysis of Real Exchange Rate and Productivity Growth of some Developing Countries in Asia
}

\author{
Md. Akhtarul Islam ${ }^{1}$ and Benojir Ahammed ${ }^{2}$ \\ ${ }^{1}$ Statistics Discipline, Khulna University, Khulna-9208, Bangladesh \\ E-mail: akhtarulstat@gmail.com \\ ${ }^{2}$ Statistics Discipline, Khulna University, Khulna-9208, Bangladesh \\ E-mail: benojirstat@ gmail.com
}

Received 28 February 2017; accepted 28 March 2017

\begin{abstract}
This paper studied the relationship between the real exchange rate and total factor productivity growth of some developing countries in Asia. To study the relationship different methodologies related to the panel data analyses are discussed in this study. We have used fixed effect analysis, robust regression, bootstrapping regression model and difference generalized method of moment estimation in our study. Panel data suggests that individuals, firms, states or countries are heterogeneous. To incorporate the country specific heterogeneity, fixed effect regression model and difference generalized method of moment estimation has been used. According to the country fixed effect model, it has been found that 10 percent depreciation of the real exchange rate is associated with a 0.10 percent increase in the average annual productivity growth rate that is, an increase in the value of real exchange rate. By using the generalized method of moment estimation it is found that 10 percent depreciation of the real exchange rate is associated with a 0.15 to 0.18 percent increase of the average annual growth rate. After analyzing the sectoral composition of output, this study showed that 10 percent depreciation of the real exchange rate is associated with a 0.5 percent increase in the average industries shares of GDP and 0.4 percent increase in the average manufacturing shares of GDP.
\end{abstract}

Keywords: Economic growth; exchange rate policy; total factor productivity growth.

AMS Mathematics Subject Classification (2010): 62P05

\section{Introduction}

Enormous evidence exists that total factor productivity (TFP) is an important determinant of economic fluctuations, economic growth, and per capita income differences across countries. It provides a more complete indicator of the economic efficiency of an industry. Total factor productivity is computed by subtracting the growth contributions of all inputs from the growth of output, so it reflects anything that causes output to grow faster than the combined growth of all inputs. The theoretical analysis of the relationship between real exchange rate and productivity suggests a double direction link. The real 


\section{Md. Akhtarul Islam and Benojir Ahammed}

exchange rate acts on productivity and on the other hand productivity affects the real exchange rate. In the first case, real exchange rate appreciation can act positively or negatively on productivity. We want to observe the impact of real exchange rate on Productivity growth of 12 Asian developing countries. McLeod and Mileva [4] showed the dynamic relationship between real exchange rate and productivity growth over the period 1975-2004 of 58 countries. They showed that 10\% real depreciation of the exchange rate leads to about $0.2 \%$ increase in the average annual total factor productivity growth rate. Kakkar and Yan [15] examined the evidence of a productivity based explanation of the long run real exchange rate movements of six Asian (Hong Kong, Indonesia, Korea, Malaysia, Singapore, and Thailand) economies. They found that the real exchange rates are co-integrated with a weighted average of the home and foreign sectoral TFP differentials. Diallo [1] studied the link between real effective exchange rate volatility and total factor productivity growth on a sample of 74 countries of six non overlapping sub-periods spanning from 1975 to 2004 and found the real effective exchange rate volatility affects negatively total factor of productivity growth. The main objectives of this paper is to find out the relationship between real exchange rate (RER) and productivity growth among the developing countries in Asia using different model. We also observe the robust relationship between RER and productivity. We find out the impact of real exchange rate onsectoral (Manufacturing, industries, agriculture, and services) composition. To eliminate the potential bias caused by omitted heterogeneity in the fixed effects, or within, estimator dynamic panel estimate of Generalized Method of Moment (GMM) estimation are obtained. For obtaining efficient estimators that account for the serial correlation Arellano-Bond [8] difference GMM and Blundell-Bond [10, 11] system GMM estimation performed.

\section{Materials and methods}

\subsection{Data description}

Panel data are conducted in this study as a form of longitudinal data, where observations on cross-section units are regularly repeated. The sample of study includes 12 countries: Bangladesh, Cyprus, India, Iran, Israel, Indonesia, Jordan, Malaysia, Pakistan, Philippines, Sri Lanka, and Thailand. The choice of the sample is based on the availability of data (period 1980 to 2009) from Asian developing countries on the basis of Gross Domestic Product (GDP) growth rate (which is 5.0-7.5). To get rid of cyclical fluctuations and focus on middle and long term relations all observations, the averages over five years have been calculated. We use the constant base year 2000. Comparing the base year we calculate all of the variables. The variable real exchange rate obtained from the estimate of McLeod and Meliva [4]. The total factor of productivity for the years from 1980 to 1990 is taken from an updated version of the Bosworth and Collins [2, 3] dataset. The remaining years are taken from the Conference Board Total Economy Database [14]. The remaining variables are obtained from the World Development Indicators (WDI) database [16]. The main variables of our study are Total Factor of Productivity (TFP), Real Exchange Rate(RER), Gross Domestic Product (GDP), Purchasing Power Parity GDP (PPPGDP), Initial real PPPGDP per capita, Secondary School Enrollment (SSE), Manufacturing (Share of GDP), Imports, Exports, Openness, Government Consumption percentage share of GDP, Services percentage share of GDP, Domestic Investment percentage share of GDP, Agriculture percentage share of GDP, Domestic Credit to Private Sector change in GDP share. The initial real GDP per capita 
An Econometric Analysis of Real Exchange Rate and Productivity Growth of some Developing Countries in Asia

calculated by taking natural log of real PPP GDP per capita in the first year of each fiveyear period [6] and the Openness is defined as the ratio of the sum of exports and imports to PPPGDP.

Total factor productivity is the best expression of the efficiency of economic production and the prospects for longer term increases in output. Higher total factor productivity indicates better level of technology, higher per worker capital, and larger returns.

The real exchange rate is the price level adjusted exchange rate. Real exchange rates are calculated as a nominal exchange rate adjusted for the different rates of inflation between the two currencies. The real exchange rate can be defined as,

$$
R=\frac{E P^{*}}{P}
$$

where, $E$ is the nominal domestic currency price of foreign currency, $P^{*}$ is the foreign price level and $P$ is the domestic price level.

\subsection{Fixed effect model}

If $Z_{i}$ is unobserved, but correlated with $X_{i t}$, then the least squares estimator of $\beta$ is biased and inconsistent as a consequence of an omitted variable. It eliminates a large portion of the total variation if the between sum of squares are large relative to the within sum of squares. However, in this instance, the model

$$
Y_{i t}=X_{i t} \beta+\alpha_{i}+\varepsilon_{i t}
$$

where $Z_{i}=z_{i} \alpha$ embodies all the observable effects and specifies an estimable conditional mean. This fixed effects approach takes $\alpha_{i}$ to be a group specific constant term in the regression model. It should be noted that the term fixed is used here indicates that the term does not vary over time, not that it is non-stochastic, where $X_{i t}$ contain observable variables that change across $t$ but not $i$, variables that change across $i$ but not $t$, and variables that change across $i$ and $t$.

\subsection{First differencing method}

The differencing method used to eliminate the unobserved effect. Lagging on time $t$ the fixed effect model from equation (1) we get,

$$
Y_{i, t-1}=X_{i, t-1} \beta+\alpha_{i}+\varepsilon_{i, t-1}
$$

By the definition of first difference we have

$$
\Delta Y_{i t}=\Delta X_{i t} \beta+\Delta \varepsilon_{i t}
$$

As with the fixed effect transformation, this first differencing transformation eliminates the unobserved effect $\alpha_{i}$.In differencing we lose the first time period for each cross section so we have $(T-1)$ time periods for each $i$, rather than $T$. If we start with $T=2$, then, after differencing, we arrive at one time period for each cross section, $\Delta Y_{i 2}=\Delta X_{i 2} \beta+\Delta \varepsilon_{i 2}$. 


\section{Md. Akhtarul Islam and Benojir Ahammed}

\subsection{Generalized method of moment (GMM) estimation}

When we analyze the fixed effects estimator, the standard assumptions are that the timevarying errors have zero means, constant variances and zero correlations, all conditional on the observed history of the covariates and on the unobserved effect. If either heteroscedasticity or serial correlation is present, a generalized method of moment's procedure can be more efficient than the fixed effect estimator. Another leading application of generalized method of moments in panel data contexts is when a model contains a lagged Arellano Bond GMM estimator. It is the estimator designed for situations with 1) "small $T$, large $N$ " panels, meaning few time periods and many individuals; 2) a linear functional relationship; 3) one left-hand-side variable that is dynamic, depending on its own past realizations; 4) independent variables that are not strictly exogenous, meaning they are correlated with past and possibly current realizations of the error; 5) fixed individual effects; and 6) heteroskedasticity and autocorrelation within individuals but not across them. Arellano Bond estimation starts by transforming all regressor, usually by differencing, and uses the generalized method of moments [7], and is called deference generalized method of moment.

Consider the simple model without exogenous regressor

$$
Y_{i t}=\rho Y_{i, t-1}+u_{i t}, u_{i t}=\alpha_{i}+\varepsilon_{i t}
$$

Anderson and Hsiao [13] showed that instrumental variable procedures consistent estimates when $\mathrm{T}$ is fixed based on first difference model transformation. The assumptions are: For all $i$, it is uncorrelated with $Y_{i 0}$ for all $t$; For all $i$, it is uncorrelated with $\alpha_{i}$ for all $t$; For all $i$, it is mutually uncorrelated. Under the assumptions, we have the set of the moment conditions:

$$
E\left(Y_{i s} \Delta u_{i t}\right)=0, t=2,3, \ldots, T, s=0,1, \ldots, t-2
$$

If serial correlation is present, we have the set of conditions

$$
E\left(Y_{i s} \Delta u_{i t}\right)=0, t=3,4, \ldots, T, s=0,1, \ldots, t-3
$$

Which gives $(T-1)(t-2) / 2$ conditions and we lost $(T-1)$ conditions.

By continuous substations seen before

$$
Y_{i t}=\varepsilon_{i t}+\rho \varepsilon_{i, t-1}+\rho^{2} \varepsilon_{t-2}+\ldots+\rho^{t-1} \varepsilon_{i 1}
$$

So that $Y_{i t}=f\left(\varepsilon_{i t}, \varepsilon_{i, t-1}, \ldots, \varepsilon_{i 1}, \alpha_{i}, y_{i 0}\right)$ and

$$
\begin{aligned}
& E\left(Y_{i, t-2} \Delta u_{i t}\right)=E\left(Y_{i, t-2}\left(\varepsilon_{i t}-\varepsilon_{i, t-1}\right)\right) E\left(\varepsilon_{i, t-2}\left(\varepsilon_{i t}-\varepsilon_{i, t-1}\right)=0,\right. \text { because by assumption } \\
& E\left(\alpha_{i} \varepsilon_{i t}\right)=E\left(\varepsilon_{i t} Y_{i 0}\right)=0
\end{aligned}
$$

\subsection{Blundell-bond GMM estimator}

Sometimes the lagged levels of the regressors are poor instruments for the first differenced regressor. In this case, one should use the augmented version "system GMM". The system GMM estimator uses the levels equation to obtain a system of two equations: one differenced and other in levels. By adding the second equation additional instruments can be obtained. Thus the variables in levels in the second equation are instrumented with their own first differences. Blundell and Bond [11] suggest using linear moment restrictions based on assumptions for initial conditions. They propose 
An Econometric Analysis of Real Exchange Rate and Productivity Growth of some Developing Countries in Asia

$E\left(u_{i t} \Delta y_{i, t-1}\right)=0, t=3,4, \ldots, T$ with the condition of $E\left(u_{i 3} \Delta y_{i 2}\right)=0$. This last condition combined with the one above implies the Ahn and Schmidt [12] nonlinear restrictions $E\left(u_{i t} \Delta y_{i, t-1}\right)=0, t=3,4, \ldots, T$.

It means that we have the following stationarity condition on the model $Y_{i 0}=\left(\frac{\alpha_{i}}{1-\rho}\right)+\varepsilon_{i 0}$.

In other terms, initial deviations from $\left(\frac{\alpha_{i}}{1-\rho}\right)$ must not be correlated with the level of $\left(\frac{\alpha_{i}}{1-\rho}\right)$ itself.

\section{Analysis and result discussion}

This chapter has been presented by the empirical results of the effects of real exchange rate and other standard variables on productivity growth and GDP based on the fixed effect regression analysis, robust regression analysis, bootstrapping sampling estimate, dynamic panel estimate of the generalized method (GMM) of moment, Arellano Bond system GMM and Blundell Bond difference GMM. Then the empirical results of the nonlinear effect of real exchange rate and other standard variables on productivity growth has been organized based on fixed effect regression and first differenced method. This chapter also contains the impact of real exchange rate on sectoral composition (Services percentage share of GDP, Domestic Investment percentage share of GDP, Agriculture percentage share of GDP, Domestic Credit to Private Sector change in GDP share).

\subsection{Impact of the real exchange rate (RER) on total factor productivity (TFP)}

We are interested to find the separate impact of the variable real exchange rate on productivity growth using fixed effect model. The term fixed is due to the fact that, although the intercept may differ across countries, each individual's intercept does not vary over time.

Table 1: Fixed effect model result between the variable TFP and RER

\begin{tabular}{|c|c|c|c|c|c|c|}
\hline \multicolumn{7}{|c|}{ Dependent Variable: TFP growth } \\
\hline & \multirow[b]{2}{*}{ Coefficient } & \multirow[b]{2}{*}{ Std. Err. } & \multirow[b]{2}{*}{$\mathrm{t}$} & \multirow[b]{2}{*}{$\mathrm{p}$-value } & \multicolumn{2}{|c|}{ 95\% Confidence Interval } \\
\hline & & & & & $\begin{array}{c}\text { Lower } \\
\text { limit }\end{array}$ & Upper limit \\
\hline RER* & 0.0102 & 0.0034 & 2.96 & 0.031 & 0.0013 & 0.0190 \\
\hline Constant & -0.5077 & 0.5211 & -0.97 & 0.375 & -1.8472 & 0.8317 \\
\hline
\end{tabular}

* Coefficient is significant at the 0.05 level; Number of observation $=72$, Number of countries $=12$, R-square value $=0.14$.; Probability $>F=0.0315$.

According to the country fixed effect panel data estimates it has been found that the estimated value of RER is 0.0102. This estimated value indicates around $10 \%$ depreciation of the real exchange rate that is an increase in the value of the variable RER 
Md. Akhtarul Islam and Benojir Ahammed

is associated with a $0.1 \%$ increase in the average annual growth rate. The p-value is 0.031 $(p<0.05)$ which indicates that RER have significant effect on the productivity growth. The $R^{2}$ value of the model is 0.14 which means that the model explain 14 percent of the total variation.

\subsection{Robust regression}

We performed the robust regression to check the validity of the estimated results. In the following table the robust regression has been performed by taking all of the variables above.

Table 2: Robust regression results

\begin{tabular}{|l|c|c|c|c|c|c|}
\hline \multicolumn{7}{|c|}{ Dependent Variable: TFP growth } \\
\hline & & \multirow{2}{*}{ Coefficient } & Std. & $\mathrm{t}$ & $\mathrm{p}-$ & \multicolumn{2}{|c|}{$\begin{array}{c}\text { 95\% Confidence } \\
\text { Interval }\end{array}$} \\
\cline { 5 - 8 } & & value & & $\begin{array}{c}\text { Lower } \\
\text { Limit }\end{array}$ & $\begin{array}{c}\text { Upper } \\
\text { Limit }\end{array}$ \\
\hline RER & 0.0030 & 0.0025 & 1.24 & 0.270 & -0.0033 & 0.0094 \\
\hline PPPGDP* & 0.1236 & 0.0368 & 3.36 & $\mathbf{0 . 0 2 0}$ & 0.0291 & 0.2182 \\
\hline $\begin{array}{l}\text { Initial real PPPGDP } \\
\text { per Capita* }\end{array}$ & -0.1593 & 0.0368 & -4.03 & $\mathbf{0 . 0 1 0}$ & -0.2609 & -0.0576 \\
\hline SSE & & & & & & \\
\hline Manufacturing * & -0.0239 & 0.0412 & -0.58 & 0.164 & -0.1146 & 0.0668 \\
\hline Openness & 0.0363 & 0.0124 & 2.93 & $\mathbf{0 . 0 1 4}$ & 0.0091 & 0.0636 \\
\hline $\begin{array}{l}\text { Government } \\
\text { Consumption } * *\end{array}$ & 0.0729 & 0.1279 & 0.57 & 0.580 & -0.2085 & 0.3545 \\
\hline Constant** & -0.1505 & 0.0597 & -2.52 & $\mathbf{0 . 0 5 3}$ & -0.3039 & 0.0029 \\
\hline
\end{tabular}

* Coefficient is significant at the 0.05 level; ** Coefficient is significant at the 0.10 level; Number of observations $=67$; Number of countries $=12$; R-square value: Within $=0.35$, between $=0.08$, Overall $=0.14$; Probability $>F=0.0018$.

In the robust regression the estimated value of coefficient of the real exchange rate is not significant and decreased than fixed effect model. Again the variables SSE and openness are not significant too. The variables PPPGDP, initial real PPPGDP per capita, manufacturing and government consumption are statistically significant but initial real PPPGDP per capita and government consumption has negative impact on TFP. In the robust regression the estimated value of coefficient of the main regressor variable real exchange rate is insignificant so, the bootstrapping regression model has been performed.

\subsection{Bootstrapping regression}

Under some regularity conditions, a bootstrap method is possible to obtain a more accurate approximation of the distribution. It is a powerful tool for approximating the distribution of complicated statistics based on independently identically distributed data. 
An Econometric Analysis of Real Exchange Rate and Productivity Growth of some Developing Countries in Asia

Table 3: Bootstrapping regression results

\begin{tabular}{|l|c|c|c|c|c|c|}
\hline \multicolumn{7}{|c|}{ Dependent Variable: TFP growth } \\
& & & & & \multicolumn{2}{c|}{$\begin{array}{c}95 \% \text { Confidence } \\
\text { Interval }\end{array}$} \\
\cline { 5 - 7 } & Coefficient & $\begin{array}{c}\text { Std. } \\
\text { Err. }\end{array}$ & $\mathrm{t}$ & $\begin{array}{c}\mathrm{p}- \\
\text { value }\end{array}$ & & \multicolumn{2}{c|}{$\begin{array}{c}\text { Lower } \\
\text { Limit }\end{array}$} & $\begin{array}{c}\text { Upper } \\
\text { Limit }\end{array}$ \\
\hline RER** & 0.0031 & 0.0133 & 0.23 & $\mathbf{0 . 0 8 2}$ & -0.0231 & 0.0292 \\
\hline PPPGDP & 0.1230 & 0.1069 & 1.16 & 0.248 & -0.0861 & 0.3333 \\
\hline $\begin{array}{l}\text { Initial real PPPGDP per } \\
\text { Capita* }\end{array}$ & -0.1593 & 0.1227 & -1.30 & $\mathbf{0 . 0 1 9}$ & -0.3998 & 0.0812 \\
\hline SSE** & & & & & & \\
\hline Manufacturing* & -0.0239 & 0.0609 & -0.39 & $\mathbf{0 . 0 7 0}$ & -0.1432 & 0.0955 \\
\hline Openness & 0.0363 & 0.0126 & 2.87 & $\mathbf{0 . 0 0 4}$ & 0.0115 & 0.0611 \\
\hline $\begin{array}{l}\text { Government } \\
\text { Consumption }\end{array}$ & 0.0729 & 0.5635 & 0.13 & 0.897 & -1.0314 & 1.1773 \\
\hline Constant & -0.1505 & 0.1216 & -1.24 & 0.216 & -0.3889 & 0.0879 \\
\hline
\end{tabular}

* Coefficient is significant at the 0.05 level; ** Coefficient is significant at the 0.10 level; Number of observations $=67$, Number of countries $=12$, R-square value: Within $=0.35$, between $=0.08$, Overall $=0.13$.

From the bootstrapping regression results it has been found that the estimated value of RER is small but significant. The estimated values of other regressors initial real PPPGDP per capita, SSE, and manufacturing are significant and only manufacturing has a positive effect. Some of regressors are insignificant because there may be some hidden causes.

\subsection{Generalized method of moment (GMM) estimation}

Generalized method of moments is convenient for estimating interesting extensions of the basic unobserved effects model. Generalized method of moments is applied more often to unobserved effects models when the explanatory variables are not strictly exogenous even after controlling for an unobserved effect. As in cross-section and time series cases, there is a convenient estimator that is consistent quite generally, but possibly inefficient relative to GMM.

Table 4: GMM estimation result

\begin{tabular}{|l|c|c|c|c|c|c|}
\hline \multicolumn{7}{|c|}{ Dependent Variable: TFP growth } \\
\hline & & \multirow{2}{*}{ Coefficient } & $\begin{array}{l}\text { Std. } \\
\text { Err. }\end{array}$ & $\mathrm{t}$ & $\begin{array}{c}\mathrm{p}- \\
\text { value }\end{array}$ & \multicolumn{2}{|c|}{$\begin{array}{c}\text { 95\% Confidence } \\
\text { Interval }\end{array}$} \\
\cline { 5 - 8 } & & & & $\begin{array}{c}\text { Lower } \\
\text { Limit }\end{array}$ & $\begin{array}{c}\text { Upper } \\
\text { Limit }\end{array}$ \\
\hline RER & 0.0113 & 0.0063 & 1.31 & 0.191 & -0.0041 & 0.0206 \\
\hline $\begin{array}{l}\text { Initial real PPPGDP } \\
\text { per Capita* }\end{array}$ & -0.0368 & 0.0143 & -2.58 & $\mathbf{0 . 0 1 0}$ & -0.0648 & -0.0088 \\
\hline Manufacturing* & 0.0208 & 0.0093 & 2.25 & $\mathbf{0 . 0 2 4}$ & 0.0027 & 0.0390 \\
\hline SSE & 0.0130 & 0.0102 & 1.28 & 0.202 & -0.0069 & 0.0330 \\
\hline Openness & 0.1070 & 0.1446 & 0.74 & 0.459 & -0.1764 & 0.3904 \\
\hline
\end{tabular}


Md. Akhtarul Islam and Benojir Ahammed

\begin{tabular}{|l|c|c|c|c|c|c|}
\hline $\begin{array}{l}\text { Government } \\
\text { Consumption }\end{array}$ & -0.0606 & 0.0400 & -1.51 & 0.130 & -0.1391 & 0.0179 \\
\hline Constant** & 1.4769 & 0.8285 & 1.78 & $\mathbf{0 . 0 7 5}$ & -0.1471 & 3.1008 \\
\hline
\end{tabular}

* Coefficient is significant at the 0.05 level; ** Coefficient is significant at the 0.10 level; Number of parameters $=7$, Number of moments $=7$, Number of observations $=67$,

Number of countries $=12$.

The dynamic panel estimates using GMM and its various instruments gives a little higher value of RER and the value is 0.0113 , which indicates that a 10 percent real depreciation leads to an increase in average TFP growth of 0.113 percent.

\subsection{Arellano bond difference GMM estimator}

Arellano and Bond [8] difference GMM is well suited for obtaining efficient estimators that account for the serial correlation.

Table 5: Arellano bond difference GMM estimator result

\begin{tabular}{|l|c|c|c|c|c|c|}
\hline \multicolumn{7}{|c|}{ Dependent Variable: TFP growth } \\
& & & & & \multicolumn{2}{|c|}{$\begin{array}{c}\text { 95\% Confidence } \\
\text { Interval }\end{array}$} \\
\cline { 5 - 7 } & Coefficient & Std. Err. & $\mathrm{t}$ & $\mathrm{p}$ \\
value & & & $\begin{array}{c}\text { Lower } \\
\text { Limit }\end{array}$ & $\begin{array}{c}\text { Upper } \\
\text { Limit }\end{array}$ \\
\hline RER & 0.0159 & 0.0138 & 1.15 & 0.273 & -0.0142 & 0.0459 \\
\hline PPPGDP & 0.0489 & 0.0562 & 0.87 & 0.401 & -0.0735 & 0.1713 \\
\hline $\begin{array}{l}\text { Initial real PPPGDP } \\
\text { per Capita* }\end{array}$ & -0.1293 & 0.0592 & -2.19 & $\mathbf{0 . 0 4 9}$ & -0.2583 & -0.0004 \\
\hline SSE & 0.0073 & 0.0274 & 0.27 & 0.795 & -0.0524 & 0.0669 \\
\hline Manufacturing** & 0.0323 & 0.0179 & 1.80 & $\mathbf{0 . 0 9 7}$ & -0.0068 & 0.0713 \\
\hline Openness* & 1.2932 & 0.5681 & 2.28 & $\mathbf{0 . 0 4 2}$ & 0.0554 & 2.5314 \\
\hline $\begin{array}{l}\text { Government } \\
\text { Consumption }\end{array}$ & -0.0730 & 0.0734 & -0.99 & 0.340 & -0.2330 & 0.0870 \\
\hline Constant** & 0.9198 & 2.9474 & 0.92 & $\mathbf{0 . 0 7 4}$ & -2.9982 & 4.6370 \\
\hline
\end{tabular}

* Coefficient is significant at the 0.05 level; ** Coefficient is significant at the 0.10 level;

Number of observations $=43$, Number of countries $=12$, Probability $>F=0.000$

Controlling for possible heterogeneity, the positive impact of RER depreciation on TFP growth is even stronger. From Arellano Bond difference GMM estimator result we have observed a 10 percent real depreciation leads to an increase in average TFP growth of 0.16 percent. The initial real PPPGDP per capita, manufacturing and openness have significant effect on TFP growth.

\subsection{Blundell bond system GMM estimation}

For estimating a dynamic TFP model using country level data, Blundell and Bond [11] find that GMM with additional moment conditions can provide more precise estimates than two stage least squares of the parameter on lagged TFP. Blundell-Bond estimator augments Arellano-Bond by making an additional assumption, that first differences of 
An Econometric Analysis of Real Exchange Rate and Productivity Growth of some Developing Countries in Asia

instrument variables are uncorrelated with the fixed effects. This allows the introduction of more instruments, and can dramatically improve efficiency.

Table 6: Blundell Bond system GMM results

\begin{tabular}{|l|c|c|c|c|c|c|}
\hline \multicolumn{7}{|c|}{ Dependent Variable: TFP growth } \\
\hline & & \multirow{2}{*}{$\begin{array}{l}\text { Std. } \\
\text { Coefficient }\end{array}$} & $\mathrm{t}$ & $\mathrm{p}$ value & \multicolumn{2}{|c|}{$\begin{array}{c}\text { 95\% Confidence } \\
\text { Interval }\end{array}$} \\
\cline { 5 - 8 } & & & & & $\begin{array}{c}\text { Lower } \\
\text { Limit }\end{array}$ & $\begin{array}{c}\text { Upper } \\
\text { Limit }\end{array}$ \\
\hline RER** & 0.0184 & 0.0316 & 0.58 & $\mathbf{0 . 0 5 6}$ & -0.0435 & 0.0803 \\
\hline PPPGDP & 0.0974 & 2.5610 & 1.46 & 0.144 & -0.1282 & 0.8758 \\
\hline $\begin{array}{l}\text { Initial real } \\
\text { PPPGDP per } \\
\text { Capita }\end{array}$ & -0.1123 & 0.0480 & -1.64 & 0.521 & -0.6391 & 1.2615 \\
\hline SSE & & & & & & \\
\hline Manufacturing** & 0.0860 & 0.6348 & -1.36 & 0.175 & -2.1046 & 0.3837 \\
\hline Openness** & 0.0282 & 0.1455 & 1.94 & $\mathbf{0 . 0 5 2}$ & -0.0029 & 0.5673 \\
\hline $\begin{array}{l}\text { Government } \\
\text { Consumption }\end{array}$ & -0.0093 & 0.5332 & 1.75 & $\mathbf{0 . 0 8 1}$ & -0.1135 & 1.9767 \\
\hline Constant* & -0.0185 & 1.2823 & 1.44 & 0.149 & -0.6640 & 4.3626 \\
\hline
\end{tabular}

* Coefficient is significant at the 0.05 level; ** Coefficient is significant at the 0.10 level; Number of observation $=44$, Number of countries $=12$, Number of instruments $=41$, Wald chi-square value $=46.50$, Probability $>\chi^{2}=0.0000$.

Blundell Bond system GMM results indicate that the positive and significant impact of RER depreciation on TFP growth is even stronger; a 10\% real depreciation leads to an increase in average TFP growth of $0.18 \%$. The manufacturing and openness also have significant effect on TFP growth.

\subsection{Impact of non-linear effect of RER on TFP}

After analyzing all tables given above it has been found that the impact of RER on TFP is positive. Linear regressions models are ones in which parameters appear linearly, but nonlinear regression models have at least one parameter appearing nonlinearly [9]. Now our interest is to see the non-linear effect of RER on TFP growth rate. To find the nonlinear effect of RER on TFP growth rate we conduct the regression analysis by taking the squared value of RER. The following table shows the results of country fixed effects regressions of TFP growth rate on the RER, the RER squared and the same control variables as above.

According to the country fixed effect estimation method the coefficient on the RER is statistically significant and positive. The value of RER is increased to 0.182 . The coefficient of the squared RER term is significant and has a negative impact. 
Md. Akhtarul Islam and Benojir Ahammed

Table 7: TFP growth and the real exchange rate tests for non-linear relationship

\begin{tabular}{|c|c|c|c|c|c|c|}
\hline \multicolumn{7}{|c|}{ Dependent Variable: TFP growth } \\
\hline & \multirow{2}{*}{$\begin{array}{c}\text { Coefficien } \\
t\end{array}$} & \multirow{2}{*}{$\begin{array}{l}\text { Std. } \\
\text { Err. }\end{array}$} & \multirow{2}{*}{$\mathrm{t}$} & \multirow{2}{*}{$\begin{array}{c}\mathrm{P} \\
\text { value }\end{array}$} & \multicolumn{2}{|c|}{$\begin{array}{l}\text { 95\% Confidence } \\
\text { Interval }\end{array}$} \\
\hline & & & & & $\begin{array}{l}\text { Lower } \\
\text { Limit }\end{array}$ & $\begin{array}{l}\text { Upper } \\
\text { Limit }\end{array}$ \\
\hline RER** & 0.0182 & 0.0419 & 0.43 & 0.066 & -0.0663 & 0.1026 \\
\hline Square of RER ** & -0.0001 & 0.0001 & -0.37 & 0.071 & -0.0004 & 0.0003 \\
\hline PPPGDP* & 0.1252 & 0.0412 & 3.04 & 0.004 & 0.0424 & 0.2079 \\
\hline $\begin{array}{l}\text { Initial real PPPGDP } \\
\text { per Capita* }\end{array}$ & -0.1622 & 0.0421 & -3.85 & 0.000 & -0.2469 & -0.0774 \\
\hline SSE & -0.0232 & 0.0415 & -0.56 & 0.579 & -0.1067 & 0.0604 \\
\hline Manufacturing* & 0.0357 & 0.0156 & 2.28 & 0.027 & 0.0042 & 0.0672 \\
\hline Openness & 0.0775 & 0.1374 & 0.56 & 0.576 & -0.1991 & 0.354 \\
\hline $\begin{array}{l}\text { Government } \\
\text { Consumption }\end{array}$ & -0.1468 & 0.0984 & -1.49 & 0.142 & -0.3448 & 0.0511 \\
\hline Constant & 3.0073 & 3.3806 & 0.89 & 0.378 & -3.7936 & 9.8083 \\
\hline
\end{tabular}

* Coefficient is significant at the 0.05 level; ** Coefficient is significant at the 0.10 level; Number of observations $=67$, Number of countries $=12$, R-square value: Within $=0.36$, between $=0.07$, Overall $=0.1344$, Probability $>\mathrm{F}=0.0052$.

\subsection{First difference method}

It has been found that there is a serial auto correlation in the data set. We could not reject the null hypothesis for second order autocorrelation that is there exits auto correlation. For this reason the first difference fixed effect estimation method is used.

Table 8: First difference regression estimations result

\begin{tabular}{|c|c|c|c|c|c|c|}
\hline \multicolumn{7}{|c|}{ Dependent Variable: TFP growth } \\
\hline & \multirow{2}{*}{ Coefficient } & \multirow{2}{*}{$\begin{array}{l}\text { Std. } \\
\text { Err. }\end{array}$} & \multirow[b]{2}{*}{$\mathrm{t}$} & \multirow{2}{*}{$\begin{array}{c}\mathrm{p} \\
\text { value }\end{array}$} & \multicolumn{2}{|c|}{$\begin{array}{c}\text { 95\% Confidence } \\
\text { Interval } \\
\end{array}$} \\
\hline & & & & & $\begin{array}{l}\text { Lower } \\
\text { Limit }\end{array}$ & $\begin{array}{l}\text { Upper } \\
\text { Limit }\end{array}$ \\
\hline RER** & 0.0219 & 0.0485 & 0.45 & 0.065 & -0.0757 & 0.1196 \\
\hline Square of RER & -0.0001 & 0.0001 & -0.41 & 0.681 & -0.0004 & 0.0002 \\
\hline PPPGDP* & 0.1120 & 0.0432 & 2.59 & 0.013 & 0.0251 & 0.1989 \\
\hline $\begin{array}{l}\text { Initial real } \\
\text { PPPGDP per } \\
\text { Capita* }\end{array}$ & -0.2139 & 0.0429 & -4.98 & 0.000 & -0.3003 & -0.1274 \\
\hline SSE* & -0.0804 & 0.0421 & -1.91 & 0.063 & -0.1652 & 0.0044 \\
\hline Manufacturing & -0.0083 & 0.0255 & -0.32 & 0.748 & -0.0596 & 0.0431 \\
\hline Openness & -0.1269 & 0.1445 & -0.88 & 0.384 & -0.4180 & 0.1641 \\
\hline $\begin{array}{l}\text { Government } \\
\text { Consumption }\end{array}$ & 0.0605 & 0.1505 & 0.40 & 0.690 & -0.2426 & 0.3637 \\
\hline Constant** & 1.6118 & 0.4664 & 3.46 & 0.001 & 0.6725 & 2.5511 \\
\hline
\end{tabular}


An Econometric Analysis of Real Exchange Rate and Productivity Growth of some Developing Countries in Asia

* Coefficient is significant at the 0.05 level; ** Coefficient is significant at the 0.10 level; Number of observations $=54$, Number of countries $=12$, R-square value $=0.48$,

Probability $>\mathrm{F}=0.0001$.

From the result of first difference, it has been observed that the coefficient of the RER is statistically significant. If it is compared to the result with the above table we find that the variables PPPGDP, initial real PPPGDP per capita, and SSE are in the first difference method are statistically significant and have significant impact on the TFP growth.

\subsection{Impact of RER on sectoral composition}

Rodrik [5] found some evidence that the effect of the RER on TFP growth operates (at least partially) through its impact on the sectoral composition of output. We also observed the effect in our study.

Table 9: Regression result of the impact of real exchange rate on the industries share of GDP

\begin{tabular}{|c|c|c|c|c|c|c|}
\hline \multicolumn{7}{|c|}{ Dependent variable: Industries (share of GDP) } \\
\hline & \multirow[t]{2}{*}{ Coefficient } & \multirow{2}{*}{ Std. Err } & \multirow{2}{*}{$\mathrm{t}$} & \multirow{2}{*}{$\begin{array}{c}\mathrm{p} \\
\text { value }\end{array}$} & \multicolumn{2}{|c|}{ 95\% Confidence Interval } \\
\hline & & & & & Lower Limit & Lower Limit \\
\hline RER* & 0.0522 & 0.0174 & 3.00 & 0.004 & 0.0173 & 0.0871 \\
\hline PPPGDP* & 0.0734 & 0.0164 & 4.49 & 0.000 & 0.0406 & 0.1063 \\
\hline Constant* & 18.9093 & 2.2899 & 8.26 & 0.000 & 14.3162 & 23.5025 \\
\hline
\end{tabular}

Table 10: Regression result of the impact of real exchange rate on agriculture share of GDP

\begin{tabular}{|c|c|c|c|c|c|c|}
\hline \multicolumn{7}{|c|}{ Dependent variable: Agriculture share of GDP } \\
\hline & \multirow[t]{2}{*}{ Coefficient } & \multirow{2}{*}{$\begin{array}{c}\text { Std. } \\
\text { Err }\end{array}$} & \multirow[t]{2}{*}{$\mathrm{t}$} & \multirow{2}{*}{$\begin{array}{c}\mathrm{p} \\
\text { value }\end{array}$} & \multicolumn{2}{|c|}{ 95\% Confidence Interval } \\
\hline & & & & & Lower Limit & Lower Limit \\
\hline RER* & -0.0135 & 0.0118 & -1.14 & 0.026 & -0.0370 & 0.0102 \\
\hline PPPGDP* & -0.1524 & 0.0111 & -13.7 & 0.000 & -0.1749 & -0.1304 \\
\hline Constant* & 32.9845 & 1.5510 & 21.27 & 0.000 & 29.874 & 36.0951 \\
\hline
\end{tabular}

Table 11: Regression result of the impact of real exchange rate on manufacturing share of GDP

\begin{tabular}{|l|c|c|c|c|c|c|}
\hline \multicolumn{7}{|c|}{ Dependent variable: Manufacturing (Share of GDP) } \\
\hline \multirow{2}{*}{ Coefficient } & \multirow{2}{*}{ Std. Err } & \multirow{2}{*}{$\begin{array}{c}\mathrm{p} \\
\text { value }\end{array}$} & \multicolumn{2}{|c|}{ 95\% Confidence Interval } \\
\cline { 5 - 7 } & & & & Lower Limit & Lower Limit \\
\hline RER & 0.0400 & 0.0931 & 0.43 & 0.669 & -0.1466 & 0.2266 \\
\hline PPPGDP* & 0.3868 & 0.0721 & 5.37 & $\mathbf{0 . 0 0 0}$ & 0.2423 & 0.5313 \\
\hline Constant & 12.1853 & 20.3336 & 1.67 & 0.101 & -4.0865 & 44.7536 \\
\hline
\end{tabular}


Md. Akhtarul Islam and Benojir Ahammed

Table 12: Regression result of the impact of real exchange rate on the Services share of GDP

\begin{tabular}{|c|c|c|c|c|c|c|}
\hline \multicolumn{7}{|c|}{ Dependent variable: Services (Share of GDP) } \\
\hline & \multirow[b]{2}{*}{ Coefficient } & \multirow[b]{2}{*}{ Std. Err } & \multirow[b]{2}{*}{$\mathrm{t}$} & \multirow[b]{2}{*}{$\begin{array}{c}\mathrm{p} \\
\text { value }\end{array}$} & \multicolumn{2}{|c|}{ 95\% Confidence Interval } \\
\hline & & & & & Lower Limit & $\begin{array}{c}\text { Lower } \\
\text { Limit }\end{array}$ \\
\hline RER** & -0.0388 & 0.0201 & -1.92 & 0.060 & -0.0793 & 0.0017 \\
\hline PPPGDP* & 0.0792 & 0.0189 & 4.17 & $\mathbf{0 . 0 0 0}$ & 0.0411 & 0.1173 \\
\hline Constant* & 48.106 & 2.6560 & 18.11 & 0.000 & 42.7790 & 53.4337 \\
\hline
\end{tabular}

* Coefficient is significant at the 0.05 level;

It has been found that from the Table 9, 10,11 and 12, the effect of the RER on TFP growth operates (at least partially) through its impact on the sectoral composition of output. It is significantly regressed the shares of industry, agriculture and service in GDP, on the RER and other independent variables. It has been found that real exchange rate associated with an increase in the manufacturing and industry shares of GDP whereas decrease in the agriculture and service share in GDP.

\section{Summary and conclusion}

This study investigates the effect of RER on TFP and the combine influences of RER, PPPGDP, initial real PPPGDP per capita, SSE, Manufacturing, openness, and government consumption on TFP by using different methods. We perform robust regression and bootstrapping to see the accuracy and identify the important factor that effect on the TFP. This study showed that, according to the country fixed effect model, real exchange rate has a significant positive effect on the productivity growth in absence of others factors for the developing country of Asia.

In this study it has been found that most of the cases the impact of manufacturing export (Change in PPPGDP share) has significant positive effect and Initial real PPPGDP per capita has significant negative effect on the productivity growth. In the presence of others factor RER has a significant effect on TFP growth for bootstrapping regression, Blundel Bond system GMM estimation, Non-linear system, and first difference method.

It has been found that the squared of the real exchange rate have negative effect on the productivity growth, which demonstrates that there is some level of the RER at which TFP growth stops increasing. This study showed that the RER depreciation is associated with an increase in the manufacturing and industry shares of GDP and a decrease in the agriculture and services shares of GDP.

At the final point, it can be said that the real exchange rate has the significant positive effect on Productivity growth. It is not the case that the effect only should be positive, it can be negative too. But this study showed a positive effect.

\section{REFERENCES}

1. A.I.Diallo, Analyzing the link between real exchange rate and productivity, Munich Personal RePEc Archive; MPRA Paper No. 29548, posted 16, March 2011.

2. B.Bosworth and S.Collins, Accounting for growth: Comparing China and India, Journal of Economic Perspectives, 22(1) (2008) 45 - 66. 
An Econometric Analysis of Real Exchange Rate and Productivity Growth of some Developing Countries in Asia

3. B.P.Bosworth and M.S.Collins, Handbook of Economic Growth, The Brookings Institution, Elsevier, 2003.

4. D.McLeod and E.Mileva, Real Exchange Rates and Productivity Growth, Discussion Paper Series, Discussion Paper No: 2011-04, Department of Economics, Fordham University.

5. D.Rodrik, The real exchange rate and economic growth. Brookings Papers on Economic Activity, 2 (2008) 365-412.

6. E.Prasad, R.Rajan and A.Subramanian, Patterns of international capital flows and their implications for economic development, presented at the symposium, The New Economic Geography: Effects and Policy Implications, The Federal Reserve Bank of Kansas City, Jackson Hole, Wyoming, 24-26 August 2006.

7. L.P.Hansen, Large sample properties of generalized method of moment's estimators. Econometrica: Journal of the Econometric Society, 50(4) (1982) 1029-1054.

8. M.Arellano and S.Bond, Some tests of specification for panel data: Monte Carlo evidence and an application to employment equations, The Review of Economic Studies, 58(2) (1991) 277-297.

9. P.K.Das, Nonlinear statistical model and its applications to diffusion of mobile telephony in India, Annals of Pure and Applied Mathematics, 5(1) (2013) 64-70.

10. R.Blundell and S.Bond, GMM Estimation with persistent panel data: an application to production functions, Econometric Reviews, 19(3) (2007) 321 - 340.

11. R.Blundell and S.Bond, Initial conditions and moment restrictions in dynamic panel data models, Journal of Econometrics, 87(1) (1998) 115 - 143.

12. S.C.Ahn and P.Schmidt, Efficient estimation of models for dynamic panel data, Journal of Econometrics, 68 (1995) 5-27.

13. T.W.Anderson and C.Hsiao, Formulation and estimation of dynamic models using panel data, Journal of Econometrics, 18 (1982) 47-82.

14. Total Economy Database, January 2012. Available on: https://www.conferenceboard.org.

15. V.Kakkar and I.K.Yan, Real exchange rates and productivity: evidence from Asia, working paper, City University of Hong Kong, 2011.

16. World Bank. World Development Indicators 2011.Available on: http://data.worldbank.org/data-catalog/world-development-indicators. 